\title{
zons

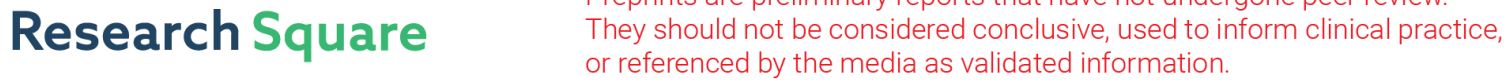 \\ Natural populations of Galphimia spp. attenuates peripheral and central inflammation
}

\section{Reinier Gesto-Borroto}

Universidad Politécnica del Estado de Morelos: Universidad Politecnica del Estado de Morelos

\section{Gabriela Meneses}

Universidad Nacional Autonoma de Mexico Direccion General de Bibliotecas: Universidad Nacional Autonoma de Mexico

\section{Alejandro Espinosa-Cerón}

Universidad Nacional Autonoma de Mexico Direccion General de Bibliotecas: Universidad Nacional Autonoma de Mexico

\section{Guillermo Granados}

Universidad Nacional Autonoma de Mexico Direccion General de Bibliotecas: Universidad Nacional Autonoma de Mexico Jacquelynne Cervantes-Torres

Universidad Nacional Autonoma de Mexico Direccion General de Bibliotecas: Universidad Nacional Autonoma de Mexico

\section{Alexandre Cardoso-Taketa}

Universidad Autonoma del Estado de Morelos

\section{Edda Sciutto}

Universidad Nacional Autonoma de Mexico Direccion General de Bibliotecas: Universidad Nacional Autonoma de Mexico

\section{Maria Luisa Villarreal ( $\nabla$ luisav@uaem.mx )}

Universidad Autonoma del Estado de Morelos https://orcid.org/0000-0003-3159-4203

\section{Research Article}

Keywords: Galphimia, nitric oxide, peripheral inflammation, central inflammation

Posted Date: March 19th, 2021

DOl: https://doi.org/10.21203/rs.3.rs-315697/v1

License: (c) (i) This work is licensed under a Creative Commons Attribution 4.0 International License. Read Full License 


\section{Abstract}

The genus Galphimia is widely distributed in Mexico, and is represented by 22 species, including medicinal species. The sedative and anti-inflammatory effects of galphimines produced by the species Galphimia glauca have been documented. Formerly, molecular studies using DNA barcodes demonstrated that nine populations botanically classified as Galphimia glauca belong to four different species of the genus Galphimia, and that only one exhibited the sedative properties; however, all the collected species showed anti-inflammatory activity. Other bioactive compounds like quercetin, galphins, galphimidins and glaucacetalins have been identified from methanolic extracts of plants botanically classified as Galphimia glauca. The aim of this work was to determine the anti-inflammatory activity of methanolic extracts of nine collected Galphimia spp. populations grown in Mexico. The possible modes of action were analyzed by evaluating the inhibition of LPS-induced inflammation processes both in vitro and in vivo. The nine populations were evaluated by an in vitro model using RAW 264.7 murine macrophage cells, and two populations (a galphimine-producing and a non-galphimine-producing population) were selected for the in vivo experiments of systemic inflammation and neuroinflammation in mice. Results suggest that an anti-inflammatory in vitro effect was present in all the studied populations, evidenced by the inhibition of nitrite production. An inhibitory systemic inflammation in mice was exerted by the two analyzed populations. In the neuroinflammation model, the anti-inflammatory effect was demonstrated in methanolic extract of the non-galphimine-producing population. For the populations of Galphimia spp. studied herein, the anti-inflammatory effect could not be correlated to the presence of galphimines.

\section{Introduction}

The genus Galphimia (Malpighiaceae) is represented in Mexico by 22 of the 26 existing species worldwide (Anderson 2007). At present, the taxonomic classification of species belonging to the genus Galphimia has been challenging and confused. The misunderstanding has been caused by the similarity in the morphology of various of the species, or by mistakes in labelling all specimens from Mexico as $G$. gracilis and G. glauca (Anderson 2007). It is reported that plants botanically classified as G. glauca have been used since pre-Hispanic times to treat different illnesses, including inflammation and central nervous disorders (Estrada 1985). Many investigations have been conducted to understand the phytochemical and pharmacological properties of G. glauca (Dorsch et al. 1992; Tortoriello and Ortega 1993; Müller et al. 1998; del Rayo et al. 2002; Cardoso-Taketa et al. 2004, 2008; Herrera-Ruiz et al. 2006; Náder et al. 2006; Ortíz et al., 2010; Sharma et al., 2012a; Abarca et al., 2014). In Mexico, Doctor Mora, Guanajuato is the locality where the first studies in a natural population botanically classified as $G$. glauca were carried out (Tortoriello and Lozoya 1992; Tortoriello and Ortega 1993; Toscano et al. 1993; Osuna et al. 1999). Subsequent studies showed that plants from this locality have anxiolytic and sedative activities in both, mice (Cardoso-Taketa et al. 2008; Sharma et al. 2012a) and humans (HerreraArellano et al. 2007, 2012; Romero-Cerecero et al. 2018). It has been demonstrated that galphimines are the bioactive compounds with the anxiolytic and sedative effects (Tortoriello and Lozoya, 1992; Cardoso- 
Taketa et al., 2008; Sharma et al., 2012a). Furthermore, anti-inflammatory effects of these metabolites have been proposed using an in vivo model in mice (González-Cortazar et al. 2014). Galphimines constitute a family of 15 (named from A to 0) nor-secofriedelane-type triterpenes (Toscano et al. 1993; Cardoso-Taketa et al. 2004; Ortega et al. 2020). Additionally, two investigations developed by our group in seven natural populations collected in the states of Chiapas, Guanajuato, Jalisco, Morelos and Querétaro, and botanically classified as G. glauca, showed that only two populations produce galphimines (CardosoTaketa et al. 2008; Sharma et al. 2012a), exhibiting anxiolytic and sedatives activities in mice; however, all of them had anti-inflammatory activity, using the tetradecanoylphorbol acetate-induced mouse ear inflammation model (TPA) (Sharma et al. 2012a). Other studies have documented the anti-inflammatory activity of G. glauca (Müller et al. 1998; González-Cortazar et al. 2014), in extracts and with pure galphimines (González-Cortazar et al. 2014). Other bioactive compounds as methyl gallate, gallic acid, quercetin, tetragalloylquinic acid, ellagic acid, galphins $A-C$, galphimidin, galphimidin $B$ and glaucacetalins A, D and E, have been isolated from plants botanically classified as $G$. glauca (Dorsch et al. 1992; Neszmélyi et al. 1993; Müller et al. 1998; del Rayo-Camacho et al. 2002; Ortíz et al. 2010; Rios et al. 2020).

In order to clarify the identity of Galphimia species, we performed two molecular studies, using DNA barcoding analysis of natural populations botanically classified as G. glauca, including the populations studied in the present investigation. These studies suggest the presence of four species of the genus Galphimia among the collected populations (Sharma et al. 2012b; Gesto-Borroto et al. 2019). In consequence, it was considered to use the term Galphimia spp. to refer to the populations here studied.

In the present investigation, individuals (six per population) from nine natural populations of Galphimia spp. were collected in different geographical locations in Mexico; five of these populations were studied for the first time. To determine the anti-inflammatory activity of methanolic extracts of all of these populations, one in vitro and two in vivo bioassays were used. These bioassays were employed for the first time to evaluate the anti-inflammatory activity from plants of Galphimia spp.

\section{Material And Methods}

\section{Plant material and extraction}

Collection of plant material was made during August and September of 2015 and 2016 in nine different locations of six states of Mexico (Table 1): Doctor Mora, Guanajuato (GM); Jalpan de Serra (QJ) and Cadereyta (QC), Querétaro; Zimapán, Hidalgo (HZ); Cuernavaca (MC), Miacatlán (MM) and Santa Catarina (MS), Morelos; Ciudad Valles, San Luis Potosí (SV) and Valparaíso (ZV), Zacatecas. Six individuals per population were collected, and specimens were deposited at the HUMO Herbarium, CIBYC (Centro de Investigación en Biodiversidad y Conservación), UAEM, Mexico, and at the HGOM Herbarium, CIB (Centro de Investigaciones Biológicas), UAEH, México. The samples (leaves) were dried for 3-4 days in a cool and dry place without direct sunlight, and then powdered by mortar and pestle. Samples were kept under $-70^{\circ} \mathrm{C}$ before to extract preparation. The methanolic extracts were prepared from all nine 
populations to evaluate the in vitro anti-inflammatory effect of Galphimia spp. Pulverized dried material (100 mg) for each sample was mixed with $1 \mathrm{~mL} \mathrm{MeOH}$. Samples were vortexed for 2 min, sonicated for $15 \mathrm{~min}$ and then centrifuged at 10,000 rpm for $15 \mathrm{~min}$. The material residue containing the pellet was reprocessed four times to achieve exhaustive extraction. The four supernatants were collected, mixed and dried at room temperature. For both in vivo anti-inflammatory assays, four samples ( $5 \mathrm{~g}$ each) of the pulverized dried material of QC and MS populations were mixed with $50 \mathrm{~mL} \mathrm{MeOH}$. Samples were vortexed for $2 \mathrm{~min}$, sonicated for $30 \mathrm{~min}$ and then centrifuged at 4,000 rpm for $30 \mathrm{~min}$. Further steps of the procedure were followed as describe above.

Table 1

General data for the studied Galphimia spp. populations.

\begin{tabular}{|c|c|c|c|c|}
\hline Population & $\begin{array}{l}\text { Voucher } \\
\text { (No.) }\end{array}$ & Locality & Date and time of collection & Curator \\
\hline GM & $15189 *$ & $\begin{array}{l}\text { Doctor Mora, } \\
\text { Guanajuato }\end{array}$ & $\begin{array}{l}\text { August } 14,2015,11: 00- \\
12: 00 h\end{array}$ & $\begin{array}{l}\text { Gabriel Flores } \\
\text { Franco }\end{array}$ \\
\hline QC & $35894^{\star}$ & Cadereyta, Querétaro & $\begin{array}{l}\text { September 10, 2015, 9:00- } \\
\text { 10:00h }\end{array}$ & $\begin{array}{l}\text { Gabriel Flores } \\
\text { Franco }\end{array}$ \\
\hline QC & $35894^{*}$ & Cadereyta, Querétaro & $\begin{array}{l}\text { September 10, 2015, 9:00- } \\
\text { 10:00h N }\end{array}$ & $\begin{array}{l}\text { Gabriel Flores } \\
\text { Franco }\end{array}$ \\
\hline MC & 15011* & Cuernavaca, Morelos & $\begin{array}{l}\text { August 24, 2015, 10:00- } \\
\text { 11:00h }\end{array}$ & $\begin{array}{l}\text { Gabriel Flores } \\
\text { Franco }\end{array}$ \\
\hline MS & $35896^{*}$ & $\begin{array}{l}\text { Santa Catarina, } \\
\text { Morelos }\end{array}$ & $\begin{array}{l}\text { August } 24,2015,12: 00- \\
13: 00 \mathrm{~h}\end{array}$ & $\begin{array}{l}\text { Gabriel Flores } \\
\text { Franco }\end{array}$ \\
\hline MM & $15426^{*}$ & Miacatlán, Morelos & $\begin{array}{l}\text { August 31, 2015, 11:00- } \\
\text { 12:00h }\end{array}$ & $\begin{array}{l}\text { Gabriel Flores } \\
\text { Franco }\end{array}$ \\
\hline $\mathrm{HZ}$ & $1483^{\star \star}$ & Zimapán, Hidalgo & $\begin{array}{l}\text { August 20, 2016, 12:00- } \\
\text { 13:00h }\end{array}$ & $\begin{array}{l}\text { Claudia Hornung } \\
\text { Leoni }\end{array}$ \\
\hline sV & $35895^{\star}$ & $\begin{array}{l}\text { Ciudad Valles, San } \\
\text { Luis Potosí }\end{array}$ & $\begin{array}{l}\text { September 17, 2016, } \\
\text { 10:00-11:00h }\end{array}$ & $\begin{array}{l}\text { Gabriel Flores } \\
\text { Franco }\end{array}$ \\
\hline ZV & $38870^{*}$ & Valparaíso, Zacatecas & $\begin{array}{l}\text { September 17, 2015, } \\
\text { 10:00-11:00h }\end{array}$ & $\begin{array}{l}\text { Gabriel Flores } \\
\text { Franco }\end{array}$ \\
\hline
\end{tabular}

\section{In vitro anti-inflammatory effect of Galphimia spp. in LPS-stimulated macrophages}

Cells

RAW 264.7 (ATCC) murine macrophage cells were cultured in DMEM/Nutrient Mixture F-12 (DMEM/F12) (Biowest) medium supplemented with 10\% heat-inactivated fetal bovine serum (FBS) (GIBCO) without 
antibiotics, in a $25 \mathrm{~cm}^{2}$ flask, at $37^{\circ} \mathrm{C}$, and $5 \% \mathrm{CO}_{2}$ atmosphere in a humidified incubator.

\section{Treatment of macrophages with lipopolysaccharide}

RAW 264.7 cells ( $2 \times 10^{5}$ cells/well) were plated into 96-well plates in $180 \mu \mathrm{L}$ DMEM/F12 medium supplemented with $10 \%$ heat-inactivated fetal bovine serum (FBS) and incubated $1 \mathrm{~h}$ at $37^{\circ} \mathrm{C}$ and $5 \% \mathrm{CO}_{2}$ atmosphere in a humidified incubator (Flores-Vallejo et al. 2020). After that, cells were treated with $20 \mu \mathrm{L}$ of methanolic extracts from Galphimia spp. at four concentration (100, 75, 50 y $25 \mu \mathrm{g} / \mathrm{mL})$, using dimethyl sulfoxide (Sigma Aldrich) at $0.5 \%$ v/v as vehicle; and aminoguanidine hydrochloride (Sigma Aldrich) at four concentrations $(100,75,50$ y $25 \mu \mathrm{g} / \mathrm{mL})$ as positive control; and they were incubated $1 \mathrm{~h}$ at the same conditions mentioned above. Macrophages were then stimulated with lipopolysaccharide (LPS, $1 \mu \mathrm{g} / \mathrm{mL}$ ) from Escherichia coli serotype 0111:B4 (Sigma Aldrich) and incubated $24 \mathrm{~h}$ to induce the nitric oxide (NO) production (Flores-Vallejo et al. 2020).

\section{Determination of nitrite concentration}

Nitrite is a stable product of the NO oxidation and its concentration was determined in the cultured medium via the Griess reaction as an indicator of NO production. Specifically, $100 \mu \mathrm{L}$ of supernatant from each well was mixed with $100 \mu \mathrm{L}$ of Griess reagent in separates 96 -well plate. After an incubation of 10 min at room temperature, the optical density was determined at $540 \mathrm{~nm}$ with a microplate reader SpectraMax® iD3.

\section{Cell viability}

Cell viability was assessed using the rezasurin assay (Ahmed et al. 1994). The cell viability assay was performed after the NO determination. Briefly, $180 \mu \mathrm{L}$ of DMEM/F12 medium supplemented with $10 \%$ heat-inactivated FBS and $20 \mu \mathrm{L}$ of rezasurin $2 \mathrm{mM}$ (Sigma Aldrich) were added to each well, and further incubated for $12 \mathrm{~h}$ at $37^{\circ} \mathrm{C}$ in a $5 \% \mathrm{CO}_{2}$ humidified incubator. The fluorescence was recorded using an excitation and emission wavelength of 544 and $590 \mathrm{~nm}$, respectively, with a microplate reader SpectraMax® iD3.

\section{In vivo anti-inflammatory effects of Galphimia spp. in LPS-treated mice Mice}

Male C57BL/ 6 mice, 7 to 8 weeks-old ( $25 \mathrm{~g}$ approx.), from a breeding colony of the Instituto de Investigaciones Biomédicas (IIB) at Universidad Nacional Autónoma de México (UNAM) were employed. Mice were divided into groups of five to six animals, and kept in polysulfon boxes with food and water ad libitum before and during the experiments. The holding room was maintained at $22 \pm 3^{\circ} \mathrm{C}$ with a $12: 12 \mathrm{~h}$ light-dark cycle.

All housing and experimental procedures were approved and conducted under the guidelines established by the Institutional Committee on the Care and Use of Experimental Animals of the IIB at UNAM (approval number ID 232).

In vivo anti-inflammatory effect of Galphimia spp. extracts in the periphery 
A model for systemic LPS-induced inflammation was employed (Qin et al. 2007; Meneses et al. 2016, 2017). Mice received $1 \mathrm{mg} / \mathrm{kg}$ of LPS or and equivalent volume of the vehicle $(0.9 \% \mathrm{NaCl}$; endotoxin-free isotonic saline solution (ISS); PiSA, Guadalajara, Mexico) administered intraperitoneally (i.p.).

\section{Treatments}

The peripheral anti-inflammatory activity of methanolic extracts of Galphimia spp. was evaluated in LPS treated mice (Fig. 1A). The anti-inflammatory effect of methanolic extracts of Galphimia spp. was evaluated employing a galphimine-producer population (QJ) and a non-galphimine-producer population (MS). Two doses of extracts from each population (200 and $600 \mathrm{mg} / \mathrm{kg}$ ) were injected i.p. after the administration of LPS dose. Two hours later mice were sacrificed by cervical dislocation, and peritoneal fluid was collected to obtain macrophages and dendritic cells.

\section{Flow cytometry}

Isolated peritoneal cells were treated following the methodology reported by Meneses et al. $(2016,2017)$. For analysis, cells were distinguished using antibodies against CD86 and MHC-II, for macrophages, as well as CD86 and CD11b for dendritic cells. Macrophage and dendritic cells activation status was assessed by examining the medium fluorescence intensity of the membrane receptors mentioned above.

\section{Anti-inflammatory effect of Galphimia spp. extracts in the LPS-induced neuroinflammation}

Mice received $5 \mathrm{mg} / \mathrm{kg}$ of LPS or and equivalent volume of the vehicle $(0.9 \% \mathrm{NaCl}$; endotoxin-free isotonic saline solution (ISS); PiSA, Guadalajara, Mexico) administered i.p.

\section{Treatments}

The anti-inflammatory effect of methanolic extracts of Galphimia spp. was evaluated employing a galphimine-producer population (QJ) and a non-galphimine-producer population (MS). One dose of each extract $(600 \mathrm{mg} / \mathrm{kg}$ ) was injected i.p. $48 \mathrm{~h}$ after the administration of LPS dose. Mice were sacrificed $24 \mathrm{~h}$ later by cervical dislocation, and brains were extracted. The expression of ionized calcium binding adaptor molecule (Iba1) and glial fibrillary acidic protein (GFAP), which are expressed specifically in microglia and astrocytes, respectively, was performed by immunofluorescence analysis (Fig. 1B).

\section{Immunofluorescence analysis}

For the immunofluorescence analysis, each brain was processed according to the methodology reported by Meneses et al. $(2016,2017)$. Brain sections were labeled with rabbit anti-GFAP (Invitrogen, Carlsbad, CA, USA), anti-lba1 (Wako Chemicals, Inc., Richmond, VA, USA) and 4',6-diamidino-2-phenylindole (DAPI), to detect astrocytes, microglia and nuclei imaging, respectively. Photographs were obtained using a digital camera attached to a light microscope (Nikon Digital Sight DS-Ri1). Regions of the hippocampus (cornu ammonis (CA1 and CA2)) and the cortex (CR1 and CR2) were selected and processed using ImageJ software (National Institute of Health, Bethesda, MD, USA).

\section{Statistical analysis}


For the analysis of nitrite concentration, and for the anti-inflammatory effect in the systemic inflammation and neuroinflammation models, data were reported as mean \pm standard deviation. For nitrite concentration determinations, and for the anti-inflammatory effect in the systemic inflammation model, statistical analysis was done by one-way ANOVA, followed by Dunnett's t-test, $p$ value 0.05 was considered to show significant difference among groups. In the neuroinflammatory experiment, statistical analysis was done by a non-parametric test (Kruskal-Wallis followed by Mann-Whitney U-test), $p$ value 0.05 was considered to show significant differences among groups. All statistical analyses were carried out using the program GraphPad Prism 6.01 (GraphPad Software Inc.).

\section{Results}

\section{In vitro inhibition of macrophage activation}

\section{Determination of nitrite concentration and cell viability}

A significant decrease using one way ANOVA in the production of nitrite (stable product of the NO oxidation) was observed in the cells treated with the four concentrations $(25,50,75$ and $100 \mu \mathrm{g} / \mathrm{mL})$ of the methanolic extracts of all studied populations of G. glauca, in comparison with the cells that were only stimulated with LPS (Fig. 2). A significant difference among the galphimines-producer and nongalphimines producer populations was not demonstrated. The value of nitrite production of macrophages that only were LPS-treated was $9.74 \pm 2.21 \mu \mathrm{M}$. The highest effect in the inhibition of nitrite production $(1.71 \pm 0.83 \mu \mathrm{M})$ was observed with the $\mathrm{HZ}$ population extract at $75 \mu \mathrm{g} / \mathrm{mL}$. Five populations showed the better results inhibiting the nitrite production in the LPS-stimulated macrophages at 100 $\mu \mathrm{g} / \mathrm{mL}$ and $75 \mu \mathrm{g} / \mathrm{mL}$, from which two (HZ and QJ) are galphimines-producer populations, and three (MM, MS and ZV) are non-galphimines producer populations. At the concentration mentioned above, the methanolic extracts of these five populations, did not showed significant differences in the production of nitrite, in comparison with the cells treated with aminoguanidine $(100 \mu \mathrm{g} / \mathrm{mL})$, or with the control macrophages without LPS (Fig. 2).

The four concentrations of the methanolic extracts were assessed to determinate its effect on the viability of the cell line RAW 264.7. None of the methanolic extracts, at any evaluated concentration showed a significant reduction on viability of the macrophages, in comparison with the cells that did not received any treatment (Fig. 3).

\section{In vivo anti-inflammatory activity}

\section{Activation of peritoneal macrophages and dendritic cells}

The activation of macrophages was evaluated identifying the CD86 and MHC-II molecules. The statistical analysis by one-way ANOVA allowed to identify a significant reduction in the percentage of macrophages $\mathrm{CD} 86+, \mathrm{CD} 86+/ \mathrm{MHC}-\mathrm{II}+$ and the medium fluorescence intensity (MFI), in mice treated with methanolic extracts of both populations; the one that produces galphimines (QJ) and the non-producer (MS), at both 
evaluated doses (200 and $600 \mathrm{mg} / \mathrm{kg}$ ), in comparison with mice that were only LPS-stimulated (Fig. 4C, D and E). The decrement in CD86 + macrophage activation was higher at $600 \mathrm{mg} / \mathrm{kg}$ with values of $44.00 \pm$ $13.45 \%$ and $47.86 \pm 10.78 \%$ for MS and QJ, respectively, in comparison with the group that only received LPS $(74.16 \pm 4.83 \%)$. The same results were obtained in the analysis of macrophages CD86+/MHC-II+, the dose of $600 \mathrm{mg} / \mathrm{kg}$ was more effective in the inhibition of the macrophages activation for both populations (MS, $50.04 \pm 13.61 \%$ and QJ, $53.90 \pm 10.51 \%$ ), in comparison with LPS-stimulated (76.80 \pm $4.79 \%$ ) (Fig. 4D). Besides, the MFI significantly decreased for CD86 + macrophages for the methanolic extracts of both populations at both analyzed doses (Fig. 4E). The reduction of the MFI was higher at 600 $\mathrm{mg} / \mathrm{kg}$ with values of $986.80 \pm 358.70$ and $1031 \pm 314.40$, for MS and QJ populations, respectively.

Dendritic cells activation was analyzed by the detection of the constitutive membrane receptor CD11b and the costimulatory receptor CD86. In the analysis of CD11b+/CD86 + dendritic cells it is not possible to refer to an anti-inflammatory effect, since significant differences between the mice LPS-stimulated, the mice without any treatment, or the mice that only received ISS, were not present. However, the MFI of CD36 was significantly reduced in mice that received the methanolic extracts of both populations evaluated at both doses (Fig. 5C). The decrease of the MFI was higher at the dose of $600 \mathrm{mg} / \mathrm{kg}$ for MS (790.85 \pm 462.3$)$ and QJ $(572.00 \pm 252.40)$ populations, in comparison with mice LPS-treated only (1931.00 \pm 440.10$)$ (Fig. 5C). No significant differences was observed for macrophages MHC-II + or dendritic cells CD $86+$ or CD11b+ (data not shown).

\section{Immunofluorescence analysis of the neuroinflammation model}

The anti-inflammatory effect of two methanolic extracts of Galphimia spp. was evaluated in an LPSinduced neuroinflammation model. The samples corresponded to a galphimine-producer population (QJ) and a non-galphimine-producer population (MS). Considering the results arose in the experiment of systemic inflammation, only the dose of $600 \mathrm{mg} / \mathrm{kg}$ was injected i.p. $48 \mathrm{~h}$ after the administration of LPS (5 mg/kg).

The visualization of Iba1 and GFAP proteins, which are expressed specifically in microglia and astrocytes, respectively, was performed by immunofluorescence analysis (Fig. 6). The quantification of Iba1 (Fig. 7) and GFAP (Fig. 8) expression was developed in the hippocampus (CA1 and CA2) and cortex (CR1 and CR2) determining the MFI of two brain sections for each mouse, in order to calculate the area on every photomicrograph and to analyze the resulting data.

The immunofluorescence analysis demonstrated that LPS increased the expression of Iba1 in microglia in the hippocampus (Fig. 7). A statistically significant reduction of the expression of Iba1 in CA1 and CA2 was observed in mice that received the methanolic extract of MS population in comparison with the group in which LPS was only administered (Fig. 7). On the other hand, the ones which received the methanolic extract of QJ population, exhibited a reduction in the expression of Iba1, in CA1 and CA2 regions; however this decrease was not significant different with the MFI of sections from mice treated only with LPS (Fig. 7). In the cortex region, no increased of Iba1 expression was observed (Fig. 7). 
In the analysis of the expression of GFAP; LPS was able to increase its presence in the CA1 region. The administration of the methanolic extracts of MS showed a reduction in the expression of GFAP, but was not significant in comparison with the group that received only LPS (Fig. 8). A reduction in the expression of GFAP in mice treated with the methanolic extract of QJ was not observed. For GFAP, neither in CR1 or CR2, an induction of inflammation was observed (Fig. 8).

\section{Discussion}

In a previous work carried out by our group, the tetradecanoylphorbol acetate (TPA)-induced mouse ear inflammation test, was performed to determine the anti-inflammatory effect of methanolic extracts of seven populations of the genus Galphimia (Sharma et al. 2012a). Four of these populations (GM, MC, $\mathrm{MM}$ and QJ) were included in this study, with other five new populations (HZ, QC, MS, SV and ZV) to further evaluate in vitro, their capacity to inhibit macrophage activation, and in vivo activity against LPSinduced peripheral and central inflammation.

In this study, we first evaluated the methanolic extracts of the nine collected populations of Galphimia spp. in an in vitro experimental model. Four of these populations (GM, HZ, QC and QJ) produce galphimines, while five (MC, MM, MS, SV and ZV) do not produce these metabolites (Gesto-Borroto et al. 2019). All the studied populations showed a similar inhibitory effect in the nitrite production.

Subsequently, a galphimine-producer population (QJ) and a nongalphimine-producer population (MS) were selected to analyze the anti-inflammatory activity in an in vivo model of LPS-induced peripheral inflammation. Two doses (200 and $600 \mathrm{mg} / \mathrm{kg}$ ) of the methanolic extracts were evaluated and the best results were obtained with the highest dose. According to the results of the peripheral inflammation model, the dose of $600 \mathrm{mg} / \mathrm{kg}$ was chosen to study the anti-inflammatory effect of the methanolic extracts in an in vivo neuroinflammation model.

For the in vitro nitrite concentration, a dose-response relationship was not demonstrated among the evaluated concentrations of the studied methanolic extracts. However, the inhibitory effect in the nitrite production increased with the highest concentration $(100 \mu \mathrm{g} / \mathrm{mL})$ of the methanolic extract, in comparison with the lowest one $(25 \mu \mathrm{g} / \mathrm{mL})$. The presence of galphimines in four (GM, HZ, QC and QJ) of the nine population here studied was demonstrated previously by means of TLC analysis (Gesto-Borroto et al. 2019). Even though the anti-inflammatory effect of galphimines have been demonstrated before in the TPA-induced mouse ear inflammation test (González-Cortazar et al. 2014), in the present work the methanolic extracts from the galphimines-producer ( $G M, H Z, Q C, Q J)$ and non-galphimine-producer (MC, $M M, M Z, S V$ and ZV) populations did not show significant differences in the inhibition of the NO synthesis. This probably indicates that other metabolites in addition to galphimines, are involved in the anti-inflammatory effect of the methanolic extracts of Galphimia spp. These results corroborates those formerly obtained by our group, in which similar anti-inflammatory effects from methanolic extracts of galphimines producer and non-producer populations were demonstrated in the TPA-induced mouse ear inflammation model (Sharma et al. 2012a). 
Otherwise, the inhibition of the nitrite production at the highest concentrations ( 100 and $75 \mu \mathrm{g} / \mathrm{mL}$ ) of five of the methanolic extracts ( $\mathrm{HZ}, \mathrm{QC}, \mathrm{MM}, \mathrm{MS}$ and $\mathrm{ZV})$ is similar to the level of nitrite production of amininoguanidine-treated cells or macrophages without any treatment, indicating a reduction of the nitrite concentration to basal levels. Furthermore being aminoguanidine a selective inhibitor of the inducible nitric oxide synthase (iNOS) (Misko et al. 1993; Corbett and McDaniel 1996), these results suggest that methanolic extracts reduced the activity of this enzyme, which is activated in macrophages that differentiate to an M1 phenotype and take part of the inflammatory process (Murray and Wynn 2011; Martinez and Gordon 2014). The methanolic extracts of Galphimia spp. did not show a cytotoxic effect over the RAW 264.7 cells, suggesting that the decrease in the nitrite production was due to an inhibition of its synthesis and not to cell death.

Regarding to the in vivo model it is well known that CD86 and MHC-II are molecules involved in T cell activation, that act as costimulatory signals and in the presentation of antigens, respectively (Ashley et al. 2012). In the evaluation of macrophages activation, for both methanolic extracts (QJ and MS) at the dose of $600 \mathrm{mg} / \mathrm{kg}$ the level of expression of CD86 did not show significant differences with regard to the mice without treatment or to those which only received ISS, hence the methanolic extracts of the population QJ and MS were decreasing to basal levels the expression of CD86 in the membrane of the macrophages (Fig. 4D).

The analysis of dendritic cells activation was performed through the detection of the constitutive membrane receptor $\mathrm{CD} 11 \mathrm{~b}$ and the costimulatory receptor $\mathrm{CD} 86 . \mathrm{CD} 11 \mathrm{~b}$ regulates cell adhesion and migration to mediate the inflammatory response (Tan et al. 2000). The statistical analysis by one-way ANOVA showed that the percentage of dendritic cells CD11b+/CD86 decreased significantly in mice that were treated with the methanolic extracts of both populations (QJ and MS) for the dose of $600 \mathrm{mg} / \mathrm{kg}$ (Fig. 5B). Nevertheless, it is not possible to clearly associate this phenomenon with an anti-inflammatory effect, since significant differences between the mice LPS-stimulated, the mice without any treatment, or the mice that only received ISS, is not present. However, the significant reduction of the MFI of CD86 in mice which received both doses (200 and $600 \mathrm{mg} / \mathrm{kg}$ ) of the two methanolic extracts (QJ and MS), in comparison with the mice that only received LPS, could be correlated with an anti-inflammatory effect. The methanolic extracts inhibited the expression of CD86, being greater to the higher doses in both populations; even for the population of QJ was significantly different in comparison with the lower doses of QJ and MS.

The reduction in the activation of macrophages and dendritic cells as a consequence of the actions of the evaluated methanolic extracts (QJ and MS) at both doses (200 and $600 \mathrm{mg} / \mathrm{kg}$ ) indicates that the LPS-induced inflammatory process was being controlled. This inhibitory effect is better with the higher doses, suggesting that higher proportion of the metabolites with an anti-inflammatory effect present in the methanolic extracts, is required in order to obtain a more effective results. Likewise in the in vitro assay, in most of the evaluations performed, no significant differences were found among the galphimine-producer population (QJ) and the non-galphimine-producer population (MS); consequently 
the anti-inflammatory effect in Galphimia spp. populations is a complex response probably due to the presence of several metabolites.

The effect of Galphimia spp. in reducing microglia/macrophages activation is consistent with the macrophages activation in the periphery. Microglia are involved in the immune defense of the brain and also contribute maintaining homeostasis. These cells could change their phenotype to an activated form, when the homeostasis in central nervous system is disrupted by different kind of damages. The uncontrolled activation of microglia induces the production of pro-inflammatory cytokines and cytotoxic mediators, which are factors implicated in neuropathological conditions (Liu et al. 2011; Meneses et al. 2017; Kabba et al. 2018; Vainchtein and Molofsky 2020). The results of this work suggest that the methanolic extract of MS population control the LPS-induced excessive activation of microglia.

In this study, we confirmed the inhibition in the expression of Iba1 protein, in mice that received the methanolic extract of MS population, suggesting a decreased of microglia/macrophages activation. Nevertheless, an inhibitory effect of the methanolic extract of QJ population was not observed, neither in Iba1 or GFAP expression. Similarly to the evaluations previously shown, no significance differences were found among the galphimine-producer population (QJ) and the non-galphimine-producing population (MS); consequently the anti-inflammatory effect it is not potentiated by galphimines. Furthermore, in the neuroinflammation model, no anti-inflammatory effect was demonstrated for the methanolic extracts of the galphimine-producer population (QJ).

\section{Conclusion}

In this work we studied nine natural population of Galphimia spp., taking into account an integrative approach involving in vitro and in vivo anti-inflammatory analyses. It was possible to demonstrate the anti-inflammatory activity of crude extracts from all the collected populations of Galphimia spp. in the in vitro model, as well as from two selected populations in two in vivo models, which were used by the first time with the genus Galphimia. The results obtained in this study support the potential use of methanolic extracts of Galphimia spp., as an alternative to treat central nervous system inflammation. The current research enabled to enhance the knowledge concerning Galphimia species in the light of its pharmacological activity. For further investigations it is necessary to identify the presence of diverse secondary metabolites with anti-inflammatory activity in the methanolic extracts of the natural populations of Galphimia spp., in order to develop a comprehensive analysis on the important antiinflammatory properties of crude extracts from plants of Galphimia species.

\section{Declarations}

\section{Funding}

Not applicable

\section{Authors' contributions}


RGB, GM, AEC, ACT, ES and MLV conceptualized the experimental procedures. RGB, GM, AEC, GG and JCT carried out the experiments. RGB, GM, AEC, ACT, ES and MLV performed the data analysis. RGB and MLV prepared the first draft of the manuscript. RGB, GM, AEC, ACT, ES and MLV edited and revised the final draft of the manuscript. All authors approved the final version for submission.

\section{Ethics approval}

All housing and experimental procedures were approved and conducted under the guidelines established by the Institutional Committee for the Care and Use of Experimental Animals of the Instituto de Investigaciones Biomédicas at Universidad Nacional Autónoma de México (approval number ID 232).

\section{Acknowledgments}

The authors are grateful to Dr. Claudia Hornung-Leoni, (Universidad Autónoma de Hidalgo), Dr. José Arturo de Nova Vázquez and MSc. Hugo Alberto Castillo Gómez (Universidad Autónoma de San Luis Potosí), and to Dr. José de Jesús Balleza (Universidad Autónoma de Zacatecas) for their support in the collection of the plant material.

\section{Conflicts of interest/Competing interests}

The authors report no conflict of interest.

\section{References}

Abarca R, Zamilpa A, Alarcón F, Herrera-Ruiz M, Tortoriello J, Jiménez Ferrer E (2014) Pharmacokinetic study in mice of galphimine-A, an anxiolytic compound from Galphimia glauca. Molecules 19:31203134. https://doi.org/10.3390/molecules 19033120

Ahmed SA, Gogal RM, Walsh JE (1994) A new rapid and simple non-radioactive assay to monitor and determine the proliferation of lymphocytes: an alternative to $\left[{ }^{3} \mathrm{H}\right]$ thymidine incorporation assay. $\mathrm{J}$ Immunol Methods 170:211-224. https://doi.org/10.1016/0022-1759(94)90396-4

Anderson C (2007) Revision of Galphimia (Malpighiaceae). Contrib Univ Michigan Herb 25:1-82

Ashley NT, Weil ZM, Nelson RJ (2012) Inflammation: mechanisms, costs, and natural variation. Annu Rev Ecol Evol Syst 43:385-406. https://doi.org/10.1146/annurev-ecolsys-040212-092530

Cardoso-Taketa AT, Lozada-Lechuga J, Fragoso-Serrano M, et al (2004) Isolation of nor-secofriedelanes from the sedative extracts of Galphimia glauca. J Nat Prod 67:644-649.

https://doi.org/10.1021/np0304666

Cardoso-Taketa AT, Pereda-Miranda R, Choi YH, Verpoorte R, Villarreal ML (2008) Metabolic profiling of the Mexican anxiolytic and sedative plant Galphimia glauca using nuclear magnetic resonance 
spectroscopy and multivariate data analysis. Planta Med 74:1295-1301. https://doi.org/10.1055/s2008-1074583

Corbett JA, McDaniel ML (1996) Selective inhibition of inducible nitric oxide synthase by aminoguanidine. Methods Enzymol 268:398-408. https://doi.org/10.1016/s0076-6879(96)68042-2

del Rayo-Camacho M, Phillipson JD, Croft SL, Marley D, Kirby GC, Warhurst DC (2002) Assessment of the antiprotozoal activity of Galphimia glauca and the isolation of new nor-secofriedelanes and norfriedelanes. J Nat Prod 65:1457-1461. https://doi.org/10.1021/np010419i

Dorsch W, Bittinger M, Kaas A, et al (1992) Antiasthmatic effects of Galphimia glauca, gallic acid, and related compounds prevent allergen- and platelet-activating factor-induced bronchial obstruction as well as bronchial hyperreactivity in guinea pigs. Int Arch Allergy Immunol 97:1-7.

https://doi.org/10.1159/000236088

Estrada E (1985) Jardín Botánico de Plantas Medicinales "Maximino Martínez". Universidad Autónoma de Chapingo, México

Flores-Vallejo R del C, Folch-Mallol JL, Sharma A, Cardoso-Taketa A, Alvarez-Berber L, Villarreal ML (2020) ITS2 ribotyping, in vitro anti-inflammatory screening, and metabolic profiling of fungal endophytes from the Mexican species Crescentia alata Kunth. South African J Bot 134:213-224. https://doi.org/10.1016/j.sajb.2019.12.030

Gesto-Borroto R, Cardoso-Taketa A, Yactayo-Chang JP, Medina-Jiménez K, Hornung-Leoni C, Lorence A, Villarreal ML (2019) DNA barcoding and TLC as tools to properly identify natural populations of the Mexican medicinal species Galphimia glauca Cav. PLoS One 14:e0217313.

https://doi.org/10.1371/journal.pone.0217313

González-Cortazar M, Herrera-Ruiz M, Zamilpa A, Jiménez-Ferrer E, Marquina S, Alvarez L, Tortoriello J (2014) Anti-inflammatory activity and chemical profile of Galphimia glauca Planta Med 80:90-96. https://doi.org/10.1055/s-0033-1360150

Herrera-Arellano A, Jiménez-Ferrer E, Zamilpa A, Morales-Valdéz M, García-Valencia CE, Tortoriello J (2007) Efficacy and tolerability of a standardized herbal product from Galphimia glauca on generalized anxiety disorder. A randomized, double-blind clinical trial controlled with lorazepam. Planta Med 73:713717. https://doi.org/10.1055/s-2007-981539

Herrera-Arellano A, Jiménez-Ferrer J, Zamilpa A, García-Alonso Griselda, Herrera-Alvarez S, Tortoriello J (2012) Therapeutic effectiveness of Galphimia glauca vs. lorazepam in generalized anxiety disorder. A controlled 15-week clinical trial. Planta Med 78:1529-1535. https://doi.org/10.1055/s-0032-1315110

Herrera-Ruiz M, Jiménez-Ferrer JE, De Lima TCM, Avilés-Montes D, Pérez-García D, González-Cortazar M, Tortoriello J (2006) Anxiolytic and antidepressant-like activity of a standardized extract from Galphimia 
glauca. Phytomedicine 13:23-28. https://doi.org/10.1016/j.phymed.2005.03.003

Kabba JA, Xu Y, Christian H, Ruan W, Chenai K, Xiang Y, Zhang L, Saavedra JM, Pang T (2018) Microglia: housekeeper of the central nervous system. Cell Mol Neurobiol 38:53-71.

https://doi.org/10.1007/s10571-017-0504-2

Liu W, Tang Y, Feng J (2011) Cross talk between activation of microglia and astrocytes in pathological conditions in the central nervous system. Life Sci 89:141-146. https://doi.org/10.1016/j.lfs.2011.05.011

Martinez FO, Gordon S (2014) The M1 and M2 paradigm of macrophage activation: time for reassessment. F1000Prime Rep 6:13. https://doi.org/10.12703/P6-13

Meneses G, Bautista M, Florentino A, Díaz G, Acero G, Besedovsky H, Meneses D, Fleury A, del Rey A, Gevorkian G, Fragoso G, Sciutto E (2016) Electric stimulation of the vagus nerve reduced mouse neuroinflammation induced by lipopolysaccharide. J Inflamm 13:33. https://doi.org/10.1186/s12950016-0140-5

Meneses G, Gevorkian G, Florentino A, Bautista MA, Espinosa A, Acero G, Díaz G, Fleury A, Pérez IN, del Rey A, Fragoso G, Sciutto E, Besedovsky H (2017) Intranasal delivery of dexamethasone efficiently controls LPS-induced murine neuroinflammation. Clin Exp Immunol 190:304-314.

https://doi.org/10.1111/cei.13018

Misko TP, Moore WM, Kasten TP, Nickols GA, Corbett JA, Tilton RG, McDaniel ML, Williamson JR, Currie MG (1993) Selective inhibition of the inducible nitric oxide synthase by aminoguanidine. Eur J Pharmacol 233:119-125. https://doi.org/10.1016/0014-2999(93)90357-N

Müller A, Reiter S, Wirth C, Wagner H (1998) Anticomplementary flavonoids from Galphimia glauca. Phytomedicine 5:341-345. https://doi.org/10.1016/S0944-7113(98)80015-9

Murray PJ, Wynn TA (2011) Protective and pathogenic functions of macrophage subsets. Nat Rev Immunol 11:723-737. https://doi.org/10.1038/nri3073

Náder BL, Cardoso-Taketa AT, Pereda-Miranda R, Villarreal ML (2006) Production of triterpenoids in liquidcultivated hairy roots of Galphimia glauca. Planta Med 72:842-844. https://doi.org/10.1055/s-2006931601

Neszmélyi A, Kreher B, Müller A, Dorsch W, Wagner H (1993) Tetragalloylquinic acid, the major antiasthmatic principle of Galphimia glauca. Planta Med 59:164-169. https://doi.org/10.1055/s-2006959635

Ortega A, Pastor-Palacios G, Ortiz-Pastrana N, Ávila-Cabezas E, Toscano RA, Joseph-Nathan P, MoralesJiménez J, Bautista E (2020) Further galphimines from a new population of Galphimia glauca.

Phytochemistry 169:112180. https://doi.org/10.1016/j.phytochem.2019.112180 
Ortíz A, Cardoso-Taketa A, Monroy MR, Rodríguez M, Arellano J, Hernández G, Villarreal ML (2010) Transformed cell suspension culture of Galphimia glauca producing sedative norffriedelanes. Planta Med 76:386-392. https://doi.org/10.1055/s-0029-1186166

Osuna L, Pereda-Miranda R, Tortoriello J, Villarreal M (1999) Production of the sedative triterpene galphimine B in Galphimia glauca tissue culture. Planta Med 65:149-152. https://doi.org/10.1055/s1999-14057

Qin L, Wu X, Block ML, et al (2007) Systemic LPS causes chronic neuroinflammation and progressive neurodegeneration. Glia 55:453-462. https://doi.org/10.1080/08927010903470815

Rios MY, Ortega A, Domínguez B, et al (2020) Glaucacetalin E and galphimidin B from Galphimia glauca and their anxiolytic activity. J Ethnopharmacol 259:112939. https://doi.org/10.1016/j.jep.2020.112939

Romero-Cerecero O, Islas-Garduño AL, Zamilpa A, Pérez-García MA, Tortoriello J (2018) Therapeutic effectiveness of Galphimia glauca in young people with social anxiety disorder: a pilot study. EvidenceBased Complement Altern Med 2018:1716939. https://doi.org/10.1155/2018/1716939

Sharma A, Cardoso-Taketa A, Choi YH, Verpoortee R, Villarreal ML (2012a) A comparison on the metabolic profiling of the Mexican anxiolytic and sedative plant Galphimia glauca four years later. J Ethnopharmacol 141:964-974. https://doi.org/10.1016/j.jep.2012.03.033

Sharma A, Folch JL, Cardoso-Taketa A, Lorence A, Villarreal ML (2012b) DNA barcoding of the Mexican sedative and anxiolytic plant Galphimia glauca. J Ethnopharmacol 144:371-378.

https://doi.org/10.1016/j.jep.2012.09.022

Tan S-M, Hyland RH, Al-Shamkhani A, Douglass WA, Shaw JM, Law SK (2000) Effect of integrin $\beta 2$ subunit truncations on LFA-1 (CD11a/CD18) and Mac-1 (CD11b/CD18) assembly, surface expression, and function. J Immunol 165:2574-2581. https://doi.org/10.4049/jimmunol.165.5.2574

Tortoriello J, Lozoya X (1992) Effect of Galphimia glauca methanolic extract on neuropharmacological tests. Planta Med 58:234-236. https://doi.org/10.1055/s-2006-961442

Tortoriello J, Ortega A (1993) Sedative effect of galphimine B, a nor-seco-triterpenoid from Galphimia glauca. Planta Med 59:398-400. https://doi.org/10.1055/s-2006-959717

Toscano RA, Ortega A, Maldonado E, Gaviño R (1993) Structure of galphimine B. Acta Crystallogr Sect C Cryst Struct Commun 49:774-776. https://doi.org/10.1107/S0108270192006644

Vainchtein ID, Molofsky AV (2020) Astrocytes and microglia: in sickness and in health. Trends Neurosci 43:144-154. https://doi.org/10.1016/j.tins.2020.01.003

\section{Figures}


A

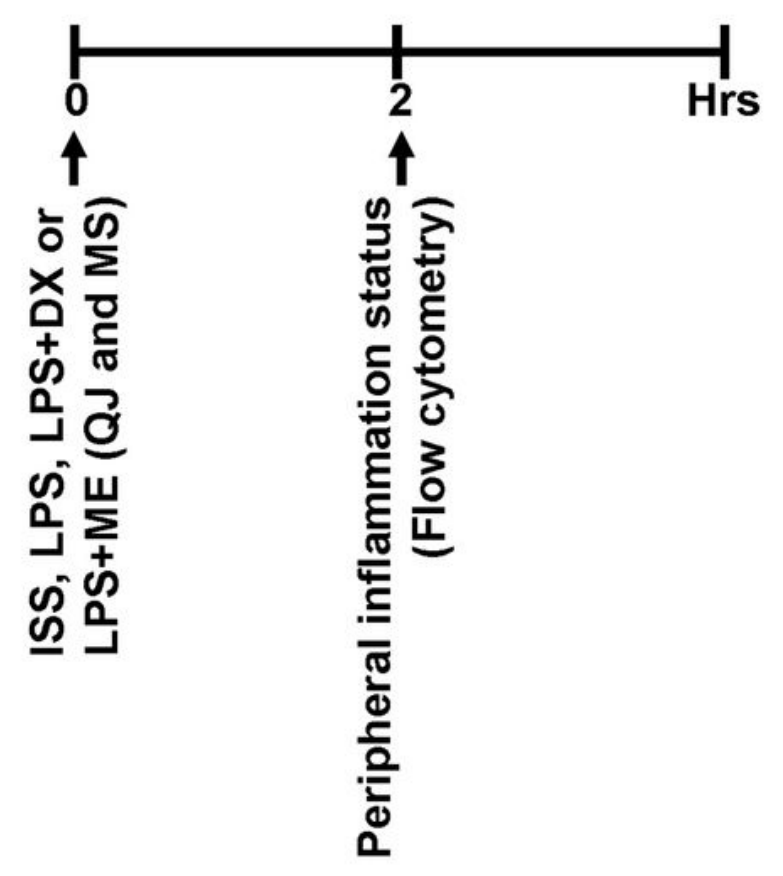

B

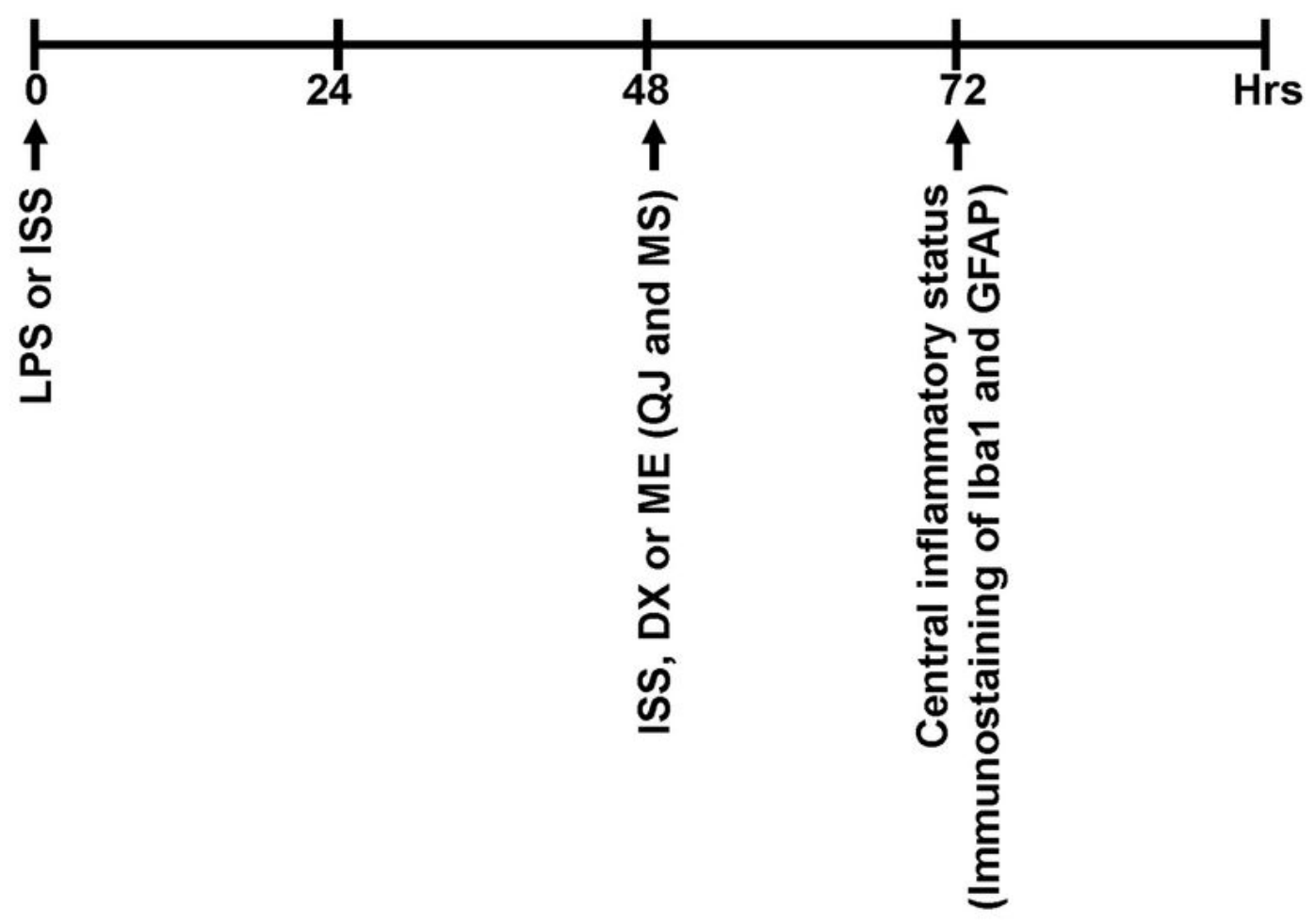

\section{Figure 1}

Experimental design. (A) Groups of five to six mice received lipopolysaccharide (LPS), isotonic saline solution (ISS) or LPS+methanolic extracts (ME) injected intraperitoneally (i.p.) (Hour 0). Two hours later, mice were sacrificed and peripheral inflammation status was evaluated. (B) Groups of five to six mice received LPS or ISS injected i.p (Hour 0). Twenty four hours later mice were treated with ISS or ME, i.p. 
Seventy two hours later mice were sacrificed and the expression of ionized calcium binding adaptor molecule 1 (Iba1) and glial fibrillary acidic protein (GFAP) was studied by immunostaining.

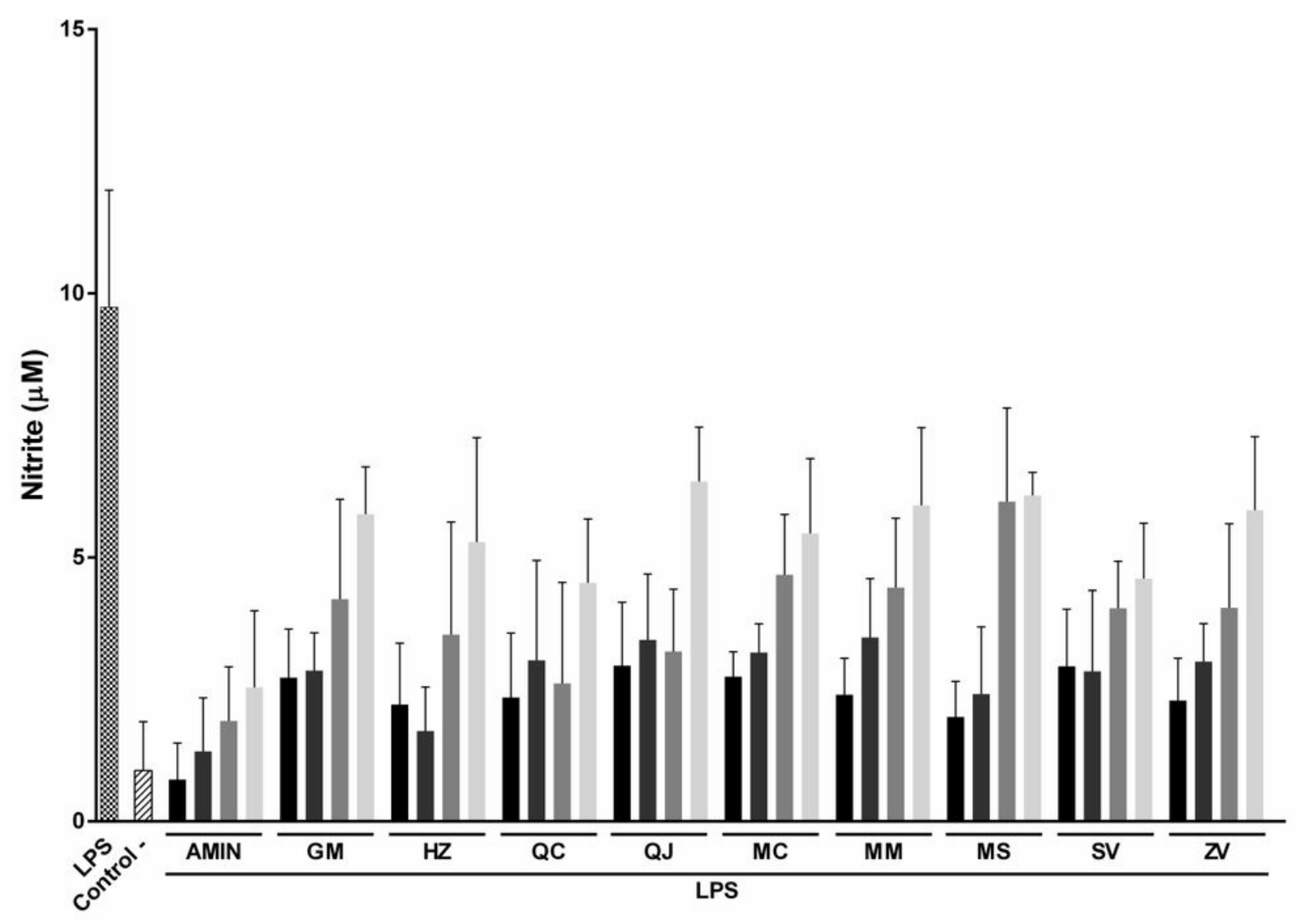

Figure 2

Effect of the methanolic extracts $(100,75,50$ and $25 \mu \mathrm{g} / \mathrm{mL})$ of Galphimia spp. on nitrite production of the LPS-treated RAW 264.7 murine macrophage cell line. A statistically significant decrease in the production of nitrite was observed in the cells treated with the four concentrations of the methanolic extracts of all populations studied, in comparison with the cells that only were stimulated with LPS. Dr. Mora, Guanajuato (GM); Zimapán, Hidalgo (HZ); Cadereyta (QC) y Jalpan de Serra (QJ), Querétaro; Cuernavaca (MC), Santa Catarina (MS) y Miacatlán (MM), Morelos; Ciudad Valles (SV), San Luis Potosí y Valparaíso, Zacatecas (ZV). AMIN: aminoguanidine hydrochloride. LPS: lipopolysaccharide. Control -: non-treated. The nitrite concentration values correspond to the mean \pm standard deviation. Significance was determined by one-way ANOVA ( $p<0.05$, compared to LPS). 


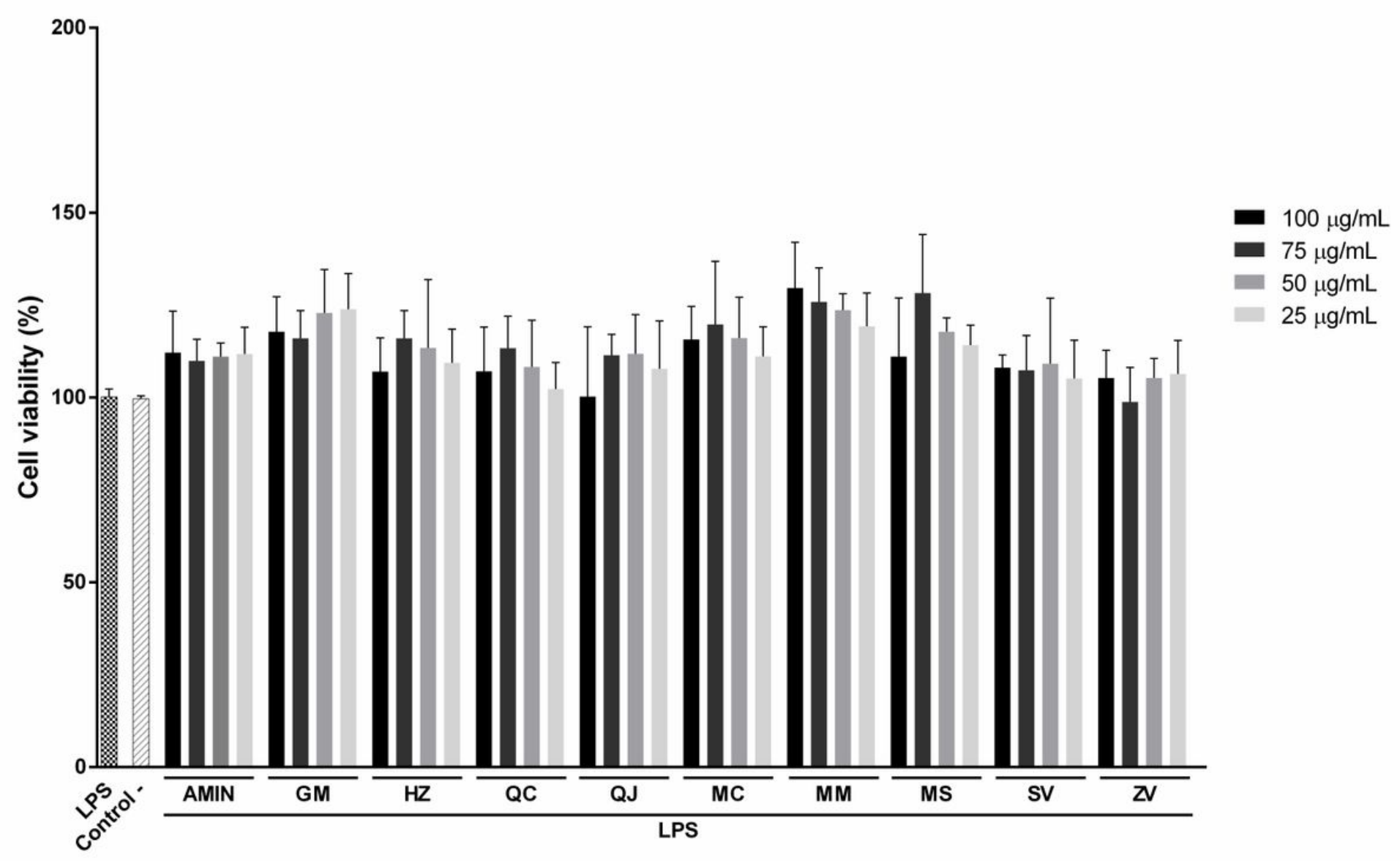

Figure 3

Effect of the methanolic extracts $(100,75,50$ and $25 \mu \mathrm{g} / \mathrm{mL})$ of Galphimia spp. on the viability of the LPS-treated RAW 264.7 murine macrophage cell line. None of the methanolic extracts show a significant reduction on viability. Dr. Mora, Guanajuato (GM); Zimapán, Hidalgo (HZ); Cadereyta (QC) y Jalpan de Serra (QJ), Querétaro; Cuernavaca (MC), Santa Catarina (MS) y Miacatlán (MM), Morelos; Ciudad Valles (SV), San Luis Potosí y Valparaíso, Zacatecas (ZV). AMIN: aminoguanidine hydrochloride. LPS: lipopolysaccharide. Control :- non-treated. The cell viability values correspond to the mean \pm standard deviation. Significance was determined by one-way ANOVA ( $p<0.05$, compared to LPS). 

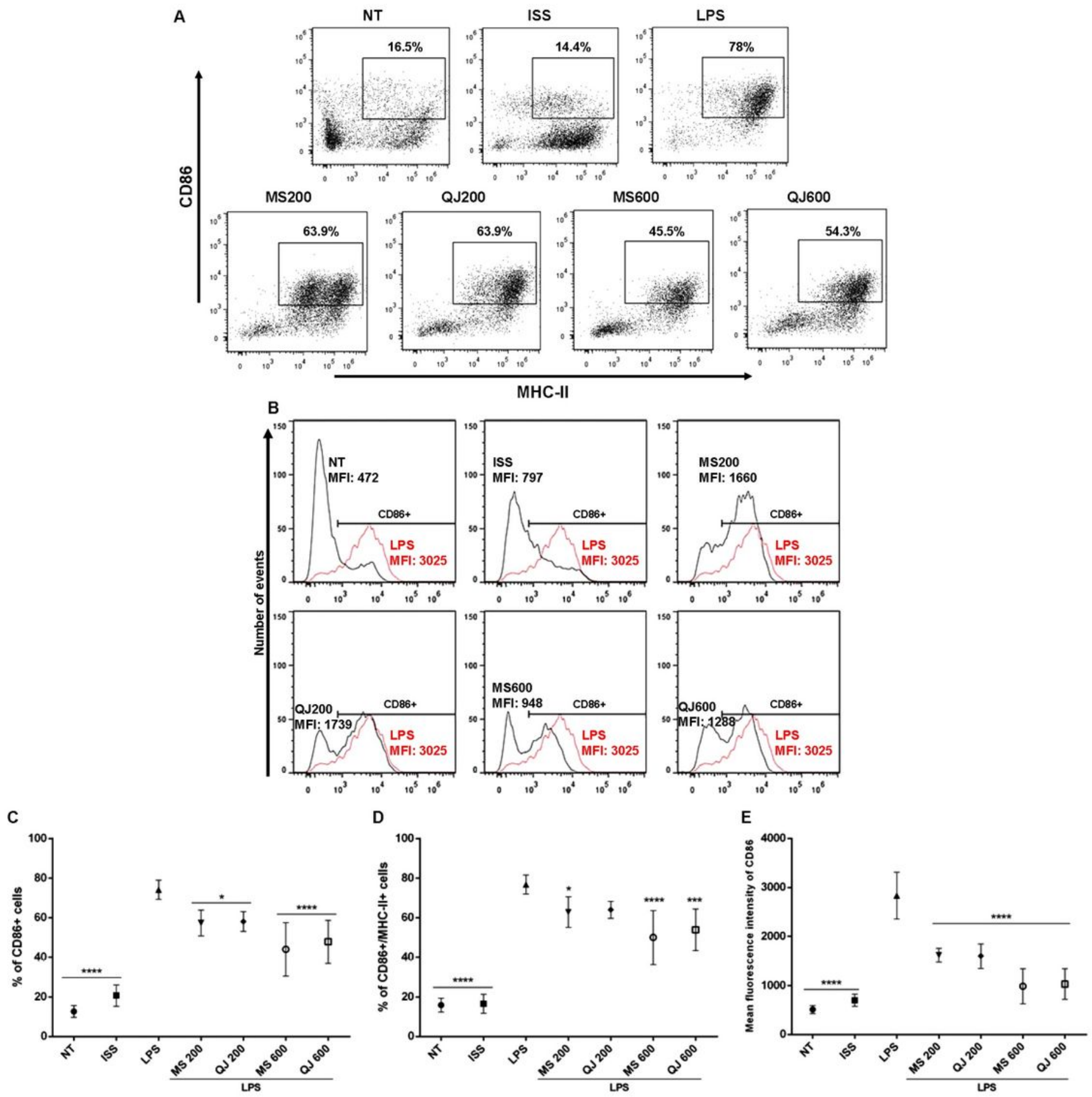

Figure 4

(A) Representative dot plot of peritoneal macrophages analyzed by flow cytometry, (B) representative histograms of medium fluorescence intensity (MFI) of CD86 of each treatment in comparison with lipopolysaccharide (LPS) treated mice, (C) percentage of CD86+ and (D) CD86+/MHC-II+, (E) MFI of CD86. NT: non-treated; ISS: isotonic saline solution; MS200 y MS600: methanolic extracts of the population of Santa Catarina, Morelos, 200 and 600 mg/kg, respectively; QJ200 y QJ600: methanolic 
extracts of the population of Jalpan de Serra, Querétaro, 200 y $600 \mathrm{mg} / \mathrm{kg}$, respectively. The percentage and MFI values correspond to the mean \pm standard deviation. Significance was determined by one-way ANOVA ( $p<0.05$, compared to LPS).
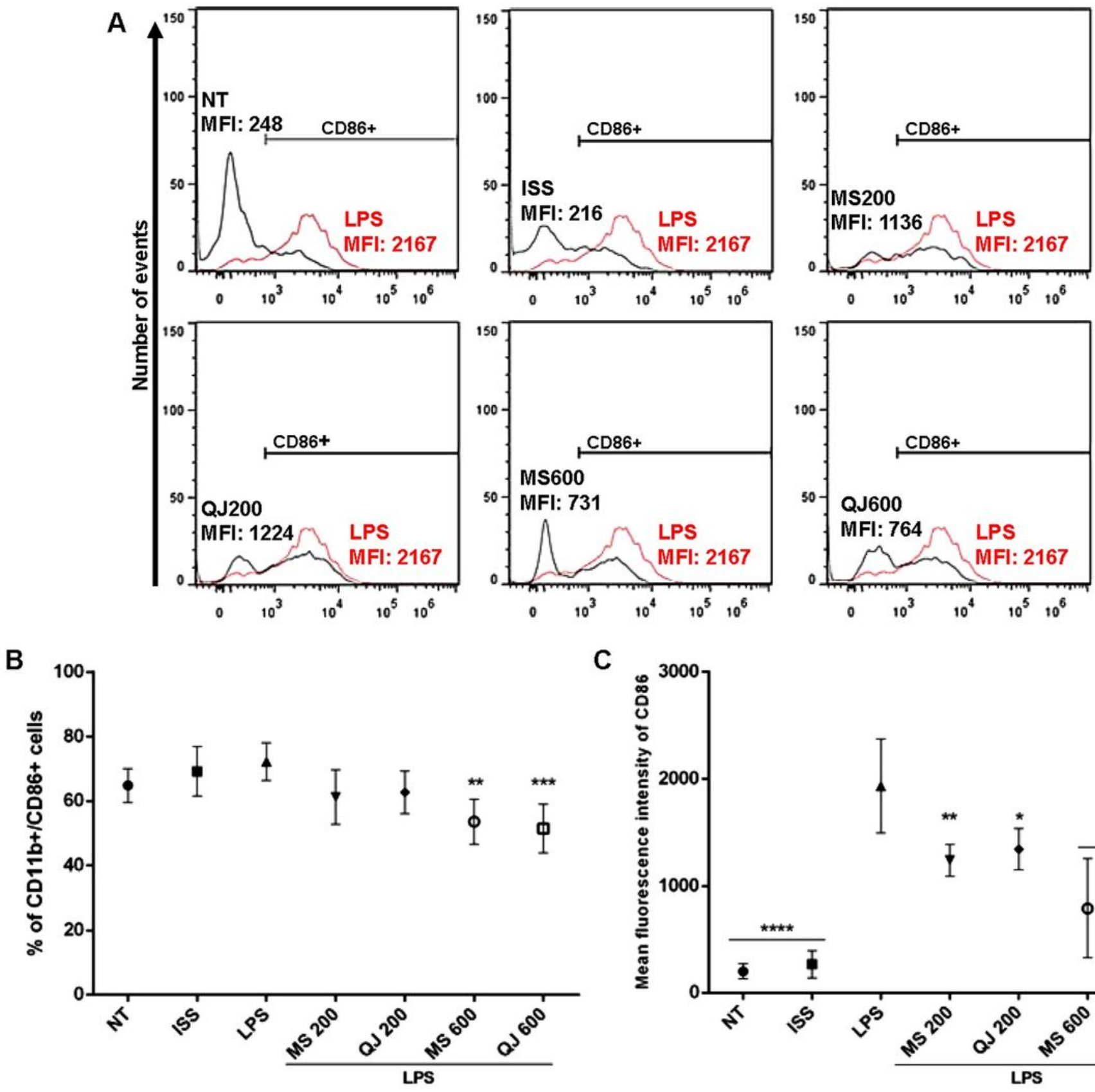

C

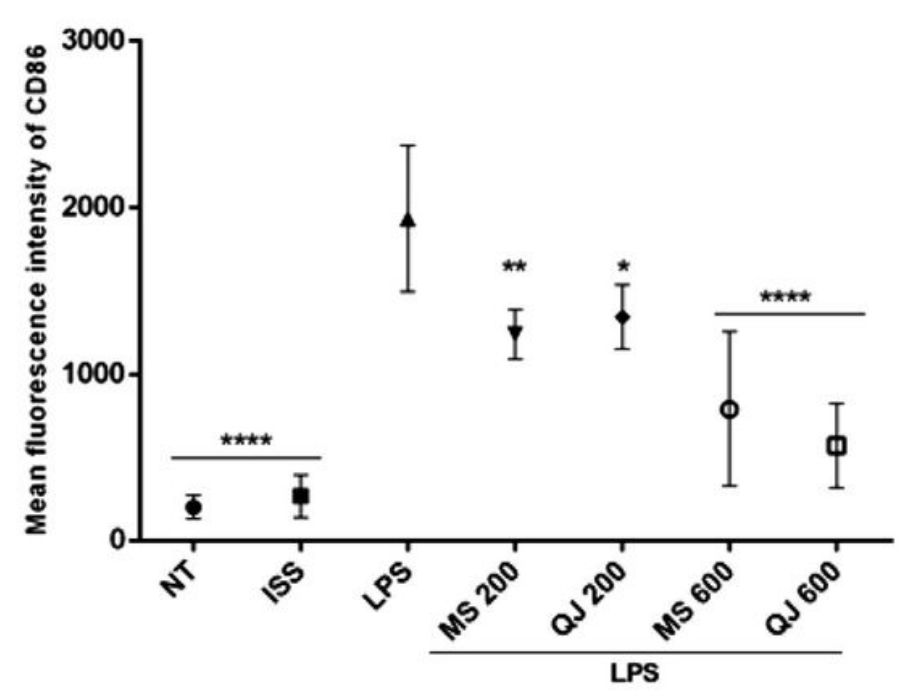

Figure 5

(A) Representative histograms of medium fluorescence intensity (MFI) of CD86 (peritoneal dendritic cells) of each treatment in comparison with lipopolysaccharide (LPS) treated mice, (B) percentage of CD11b+/CD86+ peritoneal dendritic cells, (C) MFI of CD86. NT: non-treated; ISS: isotonic saline solution; MS200 y MS600: methanolic extracts of the population of Santa Catarina, Morelos, 200 and $600 \mathrm{mg} / \mathrm{kg}$, respectively; QJ200 y QJ600: methanolic extracts of the population of Jalpan de Serra, Querétaro, 200 y 
$600 \mathrm{mg} / \mathrm{kg}$, respectively. The percentage and MFI values correspond to the mean \pm standard deviation. Significance was determined by one-way ANOVA ( $p<0.05$, compared to LPS).

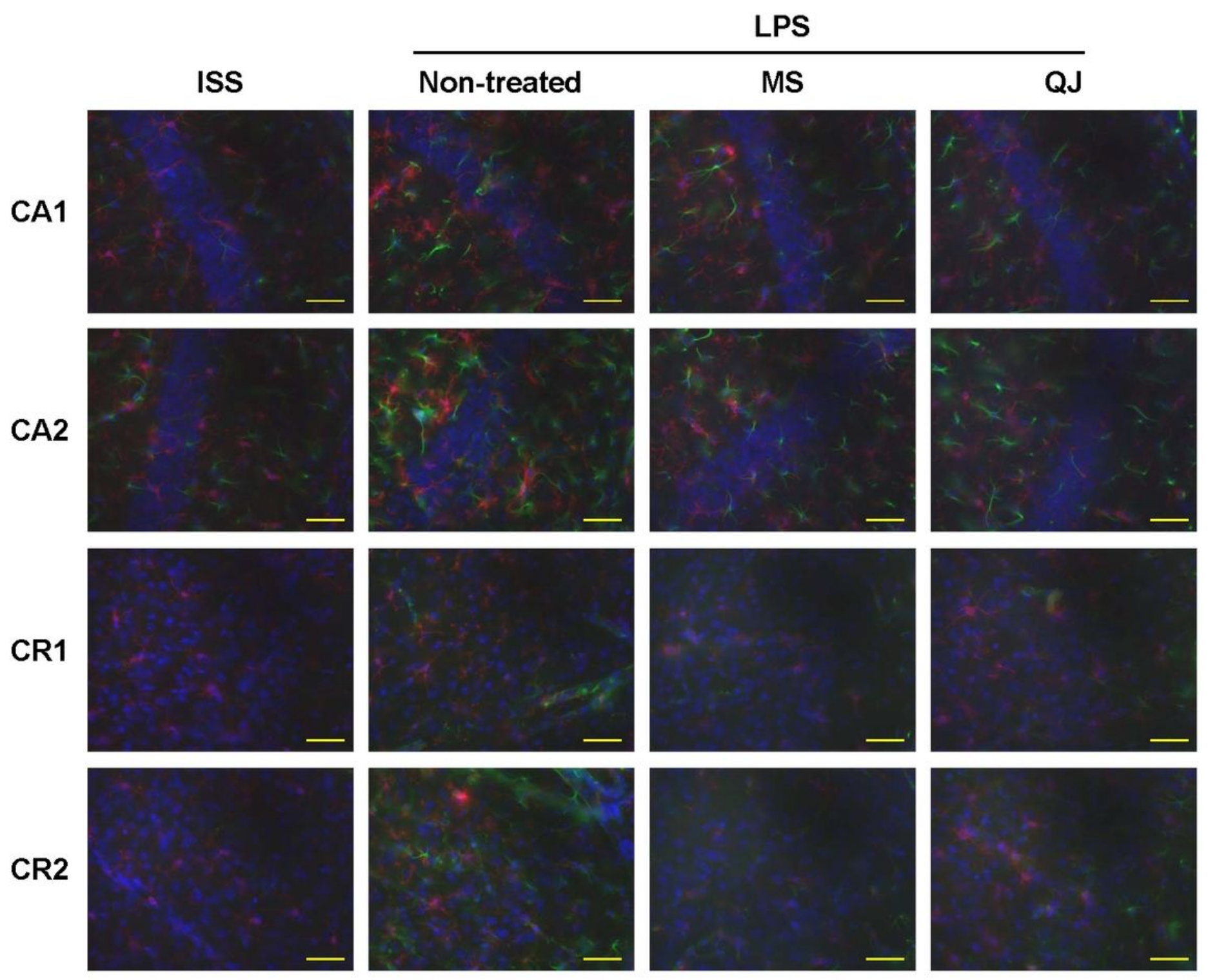

\section{Figure 6}

Glial fibrillary acidic protein (GFAP) and ionized calcium binding adaptor molecule (Iba1) expression in the four studied groups (mice that received an i.p. administration of ISS, LPS, or methanolic extracts of MS and QJ populations) of the neuroinflammation model experiment. Representative immunofluorescence of $50 \mu \mathrm{m}$ coronal sections of mouse brain of the different groups stained with antiIba 1 (red) and anti-GFAP antibodies (green) and 4',6-diamidino-2-phenylindole (DAPI) (blue nuclei). Scale bar $200 \mu \mathrm{m}$ 
LPS

A

ISS
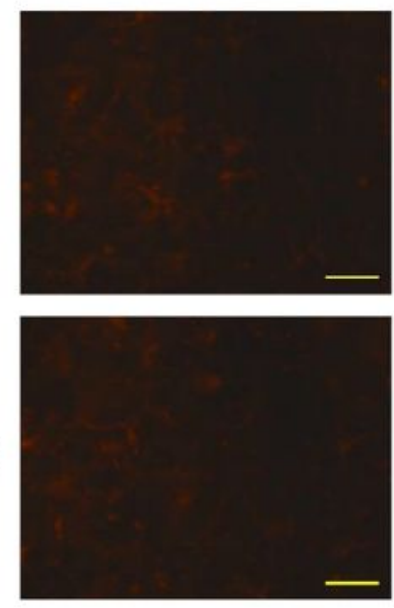

CA2

CR1
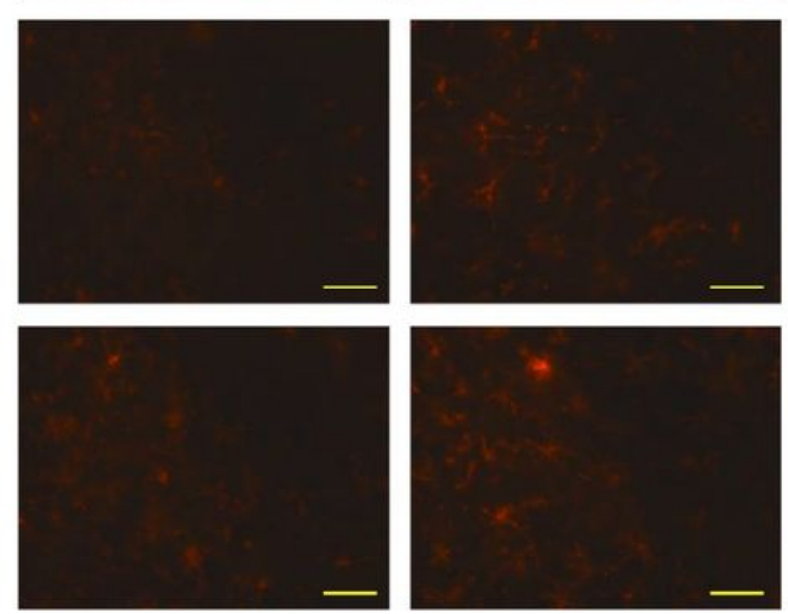

MS
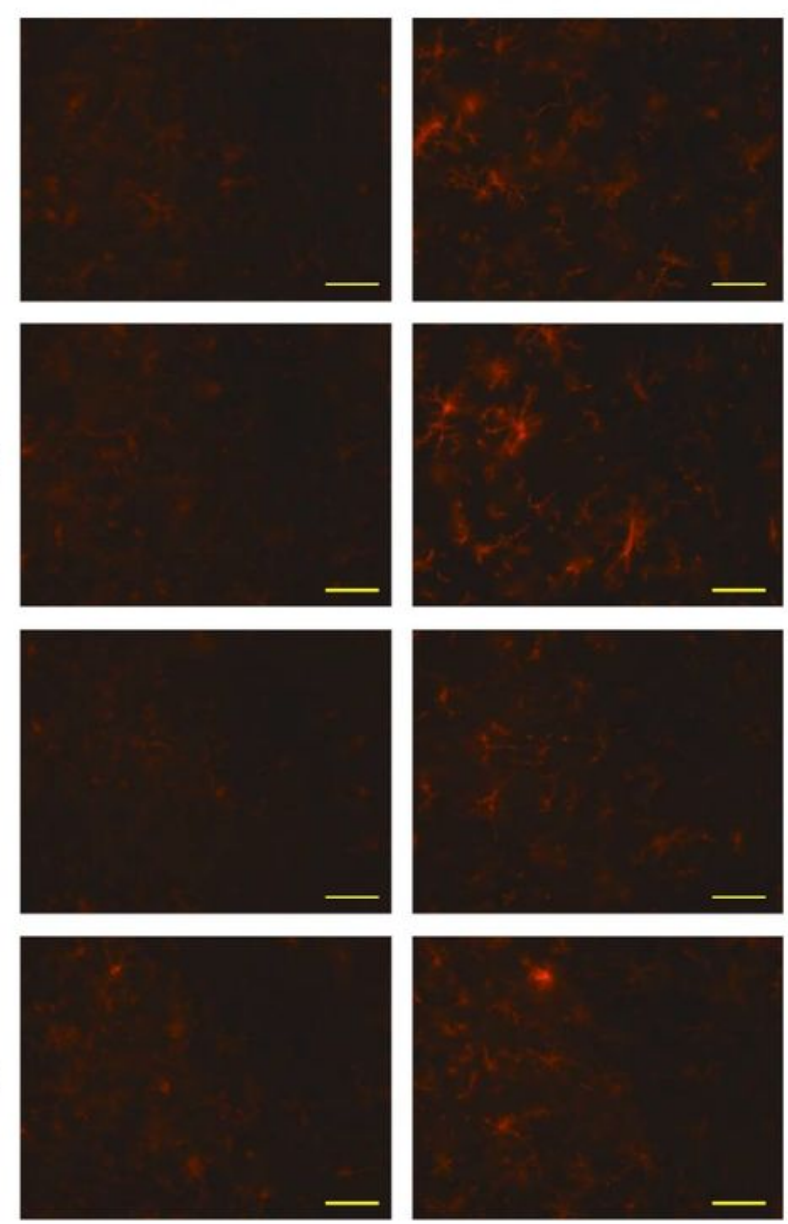
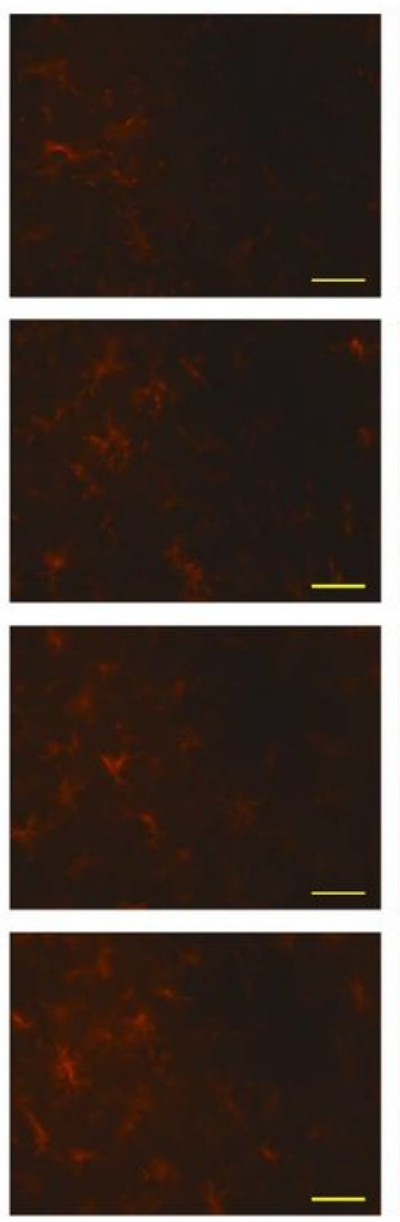

QJ
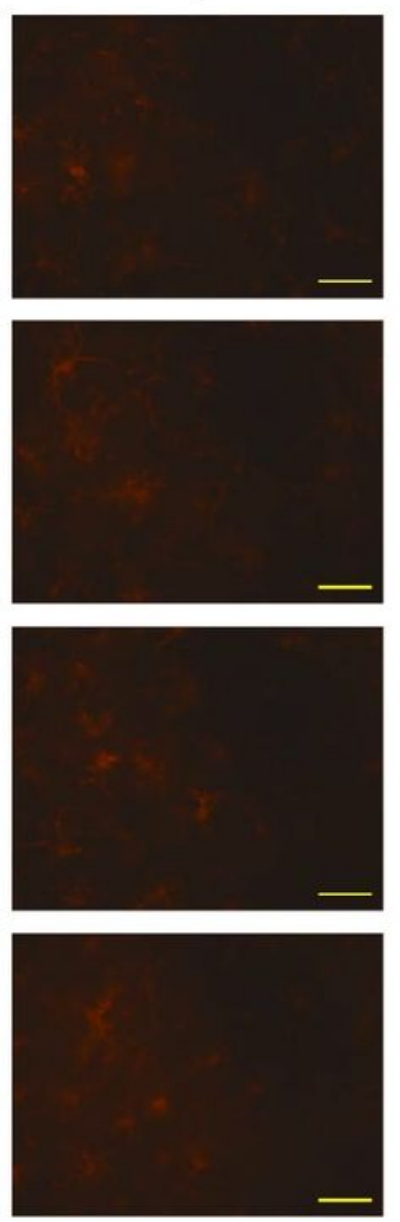

B

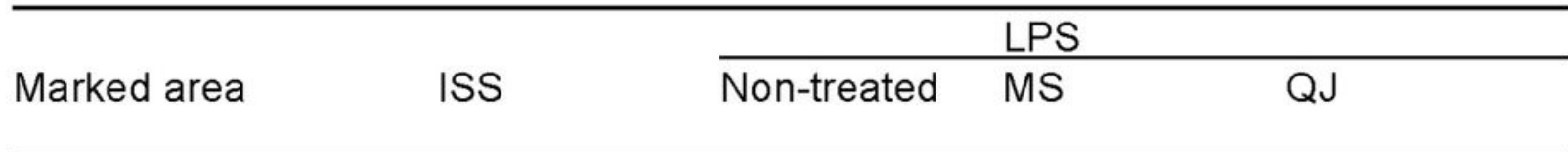

\section{Hippocampus}

$\begin{array}{lllll}\text { CA1 } & 8.73 \pm 1.14 \mathrm{~b} & 11.50 \pm 0.76 \mathrm{a} & 8.75 \pm 1.09 \mathrm{~b} & 9.24 \pm 1.47 \mathrm{ab} \\ \mathrm{CA} 2 & 8.61 \pm 1.04 \mathrm{~b} & 11.50 \pm 0.65 \mathrm{a} & 8.82 \pm 1.21 \mathrm{~b} & 9.16 \pm 1.42 \mathrm{ab}\end{array}$

\section{Cortex}

CR1

CR2

\section{Figure 7}

Immunohistological staining and quantification ionized calcium binding adaptor molecule (Iba1). (A) Representative immunofluorescence of $50 \mu \mathrm{m}$ coronal sections stained with anti-lba1 antibodies (red) in two cornu ammonis (CA1 and CA2) regions and the cortex (CR1 and CR2). The pictures derive from mice that received ISS, LPS, or the methanolic extracts of MS and QJ populations. (B) Table shows the mean \pm standard deviation of the medium fluorescence intensity. The effects of the different treatment in 
Iba1 expression in each region were compared. Data labeled with different letters are significantly different. Significance was determined by Kruskal-Wallis test ( $p$ value 0.05, compared to LPS). $200 \mu \mathrm{m}$

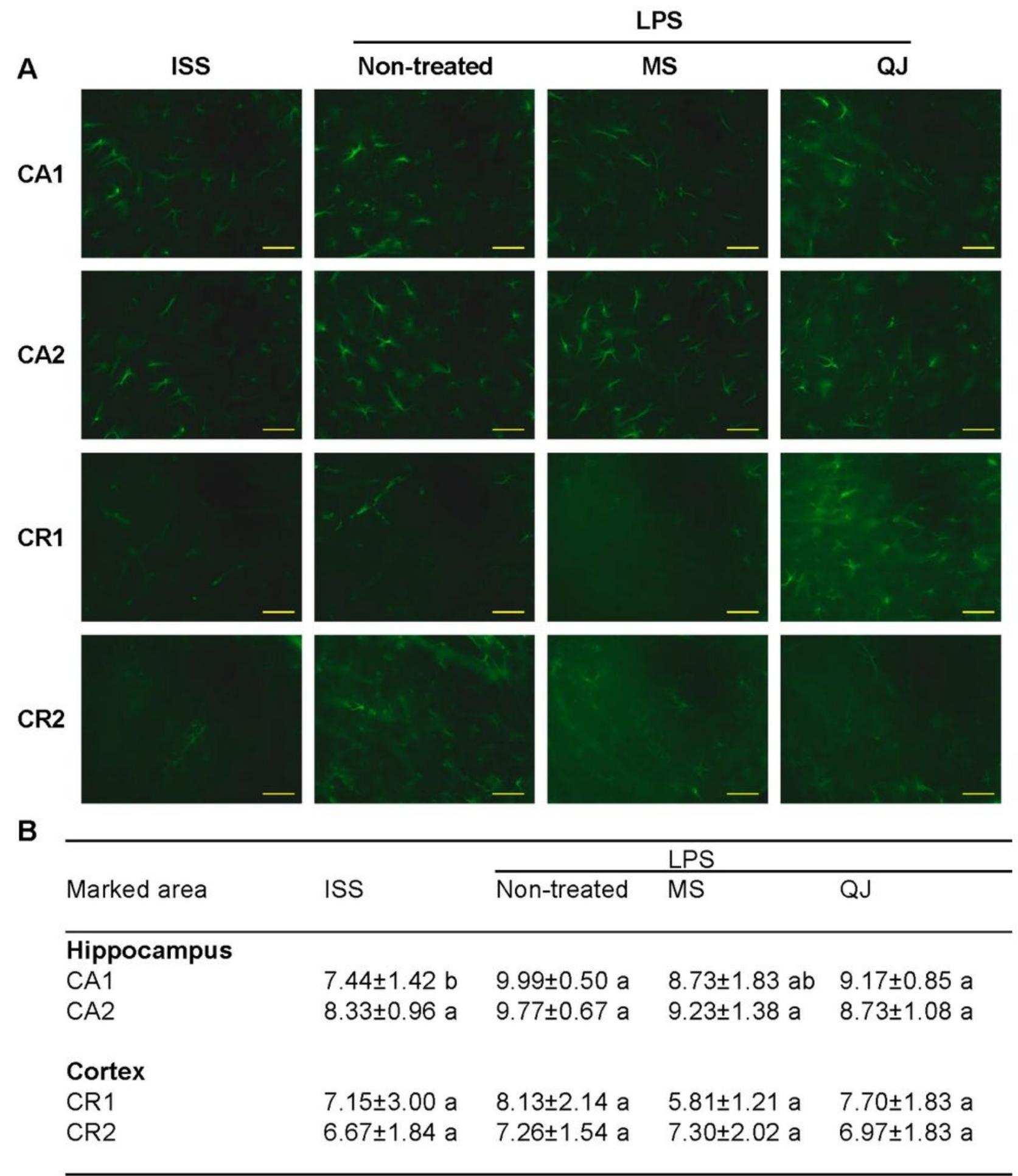

\section{Figure 8}

Immunohistological staining and quantification of glial fibrillary acidic protein (GFAP). (A) Representative immunofluorescence of $50 \mu \mathrm{m}$ coronal sections stained with anti-GFAP antibodies (green) in two cornu ammonis (CA1 and CA2) regions and the cortex (CR1 and CR2). The pictures derive from mice that 
received ISS, LPS, or the methanolic extracts of MS and QJ populations. (B) Table shows the mean \pm standard deviation of the medium fluorescence intensity. The effects of the different treatment in GFAP expression in each region were compared. Data labeled with different letters are significantly different. Significance was determined by Kruskal-Wallis test ( $p$ value 0.05 , compared to LPS). $200 \mu \mathrm{m}$ 